\title{
Impact of weather parameters in linseed (Linum usitatissimum L.) on various genotypes and sowing times
}

\author{
B.S. ROKADE, K.T. MADANE, J.D. JADHAV AND P.S. KAMBLE
}

Article Chronicle :

Received:

29.01.2015;

Revised:

22.03.2015;

Accepted :

13.04.2015

\section{Key Words :}

Weather parameters, Linseed, Genotypes, Sowing time
ABSTRACT : Split Plot Design with three replications was laid out in field experiment. The treatments consist of 6 dates of sowing $\mathrm{D}_{1}: 40^{\text {th }} \mathrm{MW}, \mathrm{D}_{2}: 41^{\text {st }} \mathrm{MW}, \mathrm{D}_{3}: 42^{\text {nd }} \mathrm{MW}, \mathrm{D}_{4}: 43^{\text {rd }} \mathrm{MW} \mathrm{D}_{5}: 44^{\text {th }} \mathrm{MW}$ and $\mathrm{D}_{6}$ : $45^{\text {th }}$ MW as main plot treatment and 3 cultivars $\mathrm{V}_{1}$ : Kiran $\mathrm{V}_{2}$ : Garima $\mathrm{V}_{3}:$ RLC-4 as sub plot treatment at College of Agriculture latur during Rabi season. First date $\left(\mathrm{D}_{1}\right)$ and second date $\left(\mathrm{D}_{2}\right)$ crop sown in MW 40 and MW 41 recorded significantly higher leaf area index than other dates of sowing. Correlation study between seed yields and weather parameters of Garima cultivar reported significant positive correlation between $\mathrm{T}_{\max }, \mathrm{T}_{\text {mean }}$, RHI, RHII, and $\mathrm{RH}_{\text {mean }}$ in $\mathrm{P}_{2}$ stage (Emergence to branching) while at critical growth stages weather had no significant effect. In respect of cultivar kiran different trend was observed in $\mathrm{P}_{4}$ stage (Flowering to capsule formation). Only $\mathrm{T}_{\min }$ and GDD have reported positive correlation. When correlation study between straw yields and weather parameters of above cultivars was to known, Garima cultivar reported significant positive association with $\mathrm{T}_{\text {min }}, \mathrm{T}_{\text {mean }}, \mathrm{RHI}, \mathrm{RHII}$ and $\mathrm{RH}_{\text {mean }}$ during $\mathrm{P}_{3}$ stage (Branching to flowering). Cultivar Kiran have also reported significant positive correlation during $\mathrm{P}_{3}$ stage (Branching to flowering). The significant negative correlation in respect of air temperature indicated that higher minimum temperatures are not ideal for optimum seed yield. The positive significant correlation of humidity values are explainable that higher air temperature indirectly decreased the humidity and there by seed yield.

How to CITE THIS ARTICLE : Rokade, B.S., Madane, K.T., Jadhav, J.D. and Kamble, P.S. (2015). Impact of weather parameters in linseed (Linum usitatissimum L.) on various genotypes and sowing times. Asian J. Environ. Sci., 10(1): 20-28. 